\title{
Examining barriers to implementation of electronic benefit transfer (EBT) in farmers markets: Perspectives from market managers
}

\author{
Anne M. Roubal, ${ }^{\text {* }}$ Alfonso Morales, ${ }^{\mathrm{b}}$ Karen Timberlake, ${ }^{\mathrm{c}}$ Ana Martinez-Donate ${ }^{\mathrm{d}}$ \\ University of Wisconsin-Madison
}

Submitted October 21, 2015 / Revised December 22, 2015, and February 23, 2016 /

Accepted February 23, 2016 / Published online June 20, 2016

Citation: Roubal, A. M., Morales, A., Timberlake, K., \& Martinez-Donate, A. (2016). Examining

barriers to implementation of Electronic Benefit Transfer in farmers markets: Perspectives from

market managers. Journal of Agriculture, Food Systems, and Community Development, 6(30, 141-161.

http://dx.doi.org/10.5304/jafscd.2016.063.011

Copyright (C) 2016 by New Leaf Associates, Inc.

\begin{abstract}
Farmers markets are generally considered one of the healthiest places to purchase food. However, less than $1 \%$ of food assistance dollars are redeemed at farmers markets. Because farmers markets have operated historically as cash operations, they are still experimenting and struggling to find ways to redeem electronic food share benefits. Much work on electronic benefit transfer (EBT) has focused on barriers from users' perspectives. Farmers markets have often been overlooked
\end{abstract}

a* Corresponding author: Anne M. Roubal, $\mathrm{PhD}$, University of Wisconsin-Madison, Department of Population Health Sciences.

Dr. Roubal is now at the University of Arizona, Center for Population Science and Discovery, Building 200A; Arizona Health Sciences; 1501 North Campbell; Tucson, Arizona 85724 USA; +1-520-626-8747; roubal@email.arizona.edu

b Alfonso Morales, University of Wisconsin-Madison, Department of Urban and Regional Planning; 104 Music Hall, 925 Bascom Mall; Madison, Wisconsin 53706 USA; +1-608263-4848; morales1@wisc.edu during the transition from food stamps to EBT. This paper takes an in-depth look at barriers and facilitators to successful implementation of EBT at farmers markets from the market manager's perspective. The researchers interviewed a semirandom geographic sample of farmers market managers across Wisconsin $(N=13)$ to determine if and how the electronic Supplemental Nutrition Assistance Program benefits are redeemed at their market and identify factors that impede or aid EBT redemption. Data were analyzed using grounded theory analysis. Several positive and negative themes emerged from the interviews as factors

${ }^{\mathrm{c}}$ Karen Timberlake, JD, University of Wisconsin Population Health Institute; 610 Walnut Street WARF 575-D; Madison, Wisconsin 53726 USA; +1-608-265-4603; ktimberlake@wisc.edu

d Ana Martinez-Donate, PhD, University of WisconsinMadison, Department of Population Health Sciences.

Dr. Martinez-Donate is now at Drexel University School of Public Health; 3215 Market Street; Nesbitt Hall 458; Philadelphia, Pennsylvania 19104 USA; apm78@drexel.edu 
associated with successful EBT programs, including community support, perceived match of EBT with market mission, stable financing, perceived benefit to vendors, and vendor acceptance of EBT. Farmers markets have the potential to reduce food insecurity through EBT redemption. Understanding the main barriers as well as effective strategies for successful implementation of EBT in farmers markets is imperative to realize the full potential of this program. Understanding difficulties from market managers' perspectives is important to inform future policy initiatives to streamline reimbursement at farmers markets.

\section{Keywords}

electronic benefit transfer, EBT, farmers market, farmers market managers, Supplemental Nutrition Assistance Program, SNAP

\section{Background}

\section{Farmers Markets and Health}

Over the past 30 years, growth in the number of farmers markets has occurred rapidly in the United States (Brown, 2001). In the last decade alone farmers markets have grown by $150 \%$ (Brown \& Miller, 2008). In 2014, 280 new farmers markets began operating in the U.S., adding to the existing 7,864 (U.S. Department of Agriculture, Agriculture Marketing Service [USDA AMS], 2014). The volume of transactions at farmers markets continues to increase as well (Holben, 2010), partly because many items cost the same or less at farmers markets and are of better quality (Wolf, Spittler, \& Ahern, 2005; Pirog \& McCann, 2009). This growth in the number of farmers markets has garnered the attention of many researchers interested in understanding the social, economic, and health impacts of farmers markets, including their role in obesity prevention efforts.

What foods individuals eat are largely the product of what foods they have access to in their environment. The Social Ecological Model (SEM) asserts that health behaviors are the product of multiple factors at the individual, household, organizational, community, and policy levels (Simons-Morton, McLeroy, \& Wendel, 2012). Factors at these multiple levels are nested within and interact with each other (Simons-Morton et al., 2012). Understanding the role of each level as well as the interactions between them is important for determining how to improve dietary patterns. The SEM has often been utilized by researchers attempting to describe how dietary patterns are affected by the multiple SEM levels (Centers for Disease Control and Prevention, 2013; FitzGerald et al., 2013). Farmers markets affect dietary patterns at the policy, community, and economic spheres of influence.

Farmers markets have many variations, but they can be defined as a "food or local product market where individual producers, primarily farmers, ranchers and local producers, bring their food wares and local goods for direct sale to the public" (University of Wisconsin-Madison \& Journal of Agriculture, Food Systems, and Community Development, n.d., para. 1). Farmers markets have several well-established relationships to health. They provide access to fresh fruits and vegetables and have been shown to improve fruit and vegetable purchasing and consumption. In a 2002 survey of customers at $21 \mathrm{New}$ Jersey farmers markets, self-reported vegetable consumption had increased over that of five years previous for $78 \%$ of the survey respondents (Govindasmy, Italia, \& Adelaja, 2002).

\section{Location of Farmers Markets}

Although little work in public health has been done to understand the factors driving the location of farmers markets, there are practical, political, and economic reasons for their location. Markets are generally located in high-traffic areas with available parking and enough space for the market and its vendors. Thus, markets are often located in city parks, parking lots, or at the intersection of streets in a downtown neighborhood. Partnerships between businesses (such as hospitals or banks) and local government buildings may allow markets to take place during nonworking hours (George, Kraschnewski, \& Rovniak, 2011). Structural elements, such as the existence of parking, electrical outlets, and public transportation nearby, may play a larger role than the economic makeup of neighborhoods when deciding where to locate farmers markets. Economic factors such as the 
presence of a grocery store or income of a community could also factor into where to locate a market. Additionally, community coalitions or organized citizens may start a market and thus its location is based on their interests.

Farmers markets are often located in higherincome, predominately white neighborhoods, where food insecurity is not a prevalent issue (Treuhaft \& Karpyn, n.d.). In order to combat food insecurity, in other neighborhoods a farmers market may form through a successful community intervention. A few successful case studies where food insecurity or the price of food was reduced through the establishment of a farmers market have been published in the scholarly literature (e.g., Larsen \& Gilliland, 2009; Neumakr-Sztainer, Story, Resnick, \& Blum, 1996). Despite attempts to use farmers markets to reduce food deserts, their customers tend to be upper-middle income, nonHispanic whites who live within 10 miles $(16 \mathrm{~km})$ of the market (Ammerman, Lindquist, Lohr, \& Hersey, 2002). These factors indicate that farmers markets currently serve as a food amenity rather than a tool to reduce food deserts.

\section{Nutrition Assistance Programs and Electronic Benefit Transfer at Farmers Markets}

Farmers markets have been viewed as locations that promote access to fruits and vegetables and, more recently, as a strategy to reduce food insecurity (Bollen, Vernez-Moedon, Kinney, \& Drewnowski, 2010; Brown 2001; Larsen \& Gilliland, 2009). Farmers markets have been most successful in improving fruit and vegetable consumption among individuals who receive Supplemental Nutrition Assistance Program (SNAP) benefits by using coupons and vouchers (Evans et al., 2012; Gustafson, Lewis, Perkins, Wilson, Bucker, \& Vail, 2013; McCormack, Laska, Larson, \& Story, 2010; Rose \& Richards, 2004). Despite recognition of the potential for farmers markets to increase access to healthy foods, more research is needed to understand how to maximize the impact of these outlets (Hendrickson, Smith, \& Eikenberry, 2006; McCormack et al., 2010). One of the main strategies used to improve access to healthy foods at farmers markets is to expand the number of markets where federal food dollars can be redeemed. This expansion of SNAP access has been slow because of the many challenges faced when transitioning the program from paper food stamps to electronic benefit transfer (EBT).

In 2002, SNAP changed from "food stamps" to an electronic benefit transfer (EBT) system, significantly changing the way food dollars were redeemed (USDA, Food and Nutrition Service [USDA FNS], 2014a). EBT systems accept federal nutrition assistance dollars via a magnetically encoded payment card. This was a dramatic change from the previous food stamp method, where coupons were given to farmers market vendors in exchange for a specific product. Under the new system, redemption of SNAP dollars at a farmers market requires a point of sale (POS) terminal to accept SNAP benefits, an active Internet connection, and the implementation of many other market processes that may exceed the limited resources of many farmers markets (Parsons \& Morales, 2013). In order to redeem EBT payments at a farmers market, the market must first finance an EBT machine. Only $18 \%$ of farmers markets nationally receive government funds to operate an EBT program; the others finance EBT machines through donations or vendor fees (Payne, 2000). EBT start-up costs run between US\$390 and US $\$ 1,000$ (Illinois Department of Agriculture, 2009; Hasin, Smith, \& Stieren, 2014). Even 12 years after its introduction, EBT remains a costly and time-consuming process and a burden to implement and operate at farmers markets (Buttenheim, Havassy, Fang, Glyn \& Karpyn, 2012; Flamm, 2011).

Since EBT was implemented, the value of SNAP dollars redeemed at farmers markets has declined drastically. The value of SNAP benefits redeemed at farmers markets dropped by $71 \%$ between 1994 (pre-EBT) and 2008 (post-EBT transition) (Briggs, Fisher, Lott, Miller, \& Tessman, 2010). Further emphasizing the struggle of farmers markets to successfully transition to EBT redemption of SNAP was the decline in percentage of redemption of all SNAP funds at farmers markets between 1992 and 2005 (Roper, 2012). Although there has been steady growth since 2007, the percentage of SNAP redemptions at farmers markets is still well under one-half that of 1992 
redemptions (Roper, 2012). These continuing low EBT redemption rates have prompted policy advocates and market managers to search for an efficient redemption method (Food Trust for Transform Wisconsin, 2014; USDA FNS, 2014b).

Farmers markets with EBT for SNAP can greatly improve the quality and quantity of food to which low-income individuals and families have access (Jones \& Bhatia, 2011). However, the extent to which farmers markets participate in EBT and the mechanisms for accepting SNAP dollars electronically at farmers markets is poorly understood. Reasons for accepting EBT at farmers markets are often economically motivated, and not due to the health benefits (Ward, Slawson, Wu, \& Jilcott Pitts, 2015). Yet offering SNAP redemption at farmers markets has been shown to increase fruit and vegetable intake among SNAP beneficiaries (Jones \& Bhatia, 2011; Krokowski, 2014; Ruelas, Iverson, Kiekel, \& Peters, 2012). Adoption of EBT in farmers market continues to be limited in nature. In Wisconsin, $15 \%$ of the state's population receives SNAP funding, but only $14 \%$ of farmers markets accept EBT (Food Trust for Transform Wisconsin, 2014; USDA AMS, n.d.). Furthermore, only $0.015 \%$ of the federal food benefit dollars issued in Wisconsin is redeemed at farmers markets (Roper \& Miller, 2013). This is slightly lower than the general U.S. estimate that American consumers spend almost $0.2 \%$ of their food dollars at farmers markets (Briggs et al., 2010).

Many farmers markets have expanded their electronic money transfer services to include credit and debit cards in addition to SNAP funds. This can be expanded to the vendor level with devices such as the Square or other chip readers (Buttenheim et al., 2012). These devices increase the purchasing power of individuals who do not need to rely on cash or check to buy produce.

Other nutrition assistance programs at farmers markets have been analyzed in studies. However, these studies have been limited in scope to either one or a few farmers markets and have not evaluated the EBT reimbursement process, since both the Special Supplemental Nutrition Program for Women, Infants, and Children (WIC) and the Senior Farmers' Market Nutrition Program (SFMNP) programs still operate using paper exchange processes. A study of the SFMNP in South Carolina indicated that farmers benefited from the program through increased produce sales and that program participants intended to eat more produce because of the program (Kunkel, Luccia, $\&$ Moore, 2003). An evaluation of a similar program in Massachusetts indicated that SFMNP vouchers were successful in attracting new customers to the farmers market (Balsam, Webber, \& Oehlke, 1994). In a Connecticut study, researchers found that use of WIC vouchers increased visits to the farmers market but not consumption of fruits and vegetables (Anliker, Winne, \& Drake, 1992). Studies in California and Michigan, however, found modest increases in fruit and vegetable consumption through WIC supplements for farmers markets (Anderson et al., 2001; Herman, Harrison, Afifi, \& Jenks, 2008; Joy, Bunch, Davis, \& Fujii, 2001). Furthermore, it has been suggested that simply by having access to the WIC supplement, farmers market received increased visits, and hopefully their consumers had additional fruit and vegetable consumption over the long term (National Association of Farmers' Market Nutrition Programs, 2001). Consumers who received the FMNP supplement in addition to WIC had higher perceived benefits and quality of foods as well as increased vegetable intake (Kropf, Holben, Holcomb, \& Anderson, 2007). A study on 2011 SNAP redemption at farmers markets indicated that fruit and vegetable consumption increased among SNAP participants (Young et al., 2013). Furthermore, SNAP sales doubled at farmers in low-income areas in the first two years of the program (Young et al., 2013).

Much work has focused on individual barriers to using EBT at farmers markets from the vendor or customer perspective. Barriers to EBT redemption at the customer level include limited hours, limited locations, lack of child care, price, selection of foods, and difficulty of using the EBT card (Grace, Grace, Becker, \& Lyden, 2007; Leone et al., 2012; Suarez-Balcazar, Martinez, Cox, \& Jayraj, 2006; USDA, 2014b). In one study that looked at vendors' perspective, $51 \%$ of vendors judged the program to be unsuccessful (Krokowski, 2014). Perceived challenges to the program included marketing challenges and having to send customers 
to the EBT station from their stalls for redemption (Krokowski, 2014). On the other hand, 80\% of farmers market managers believed that the EBT program was a success at their markets, although they recognized that the largest challenges were related to time and operational logics (Krokowski, 2014). To date, very few solutions have been offered to assist managers in overcoming those barriers.

This paper investigates the processes, facilitators, and barriers encountered by farmers market managers when initiating a EBT program, using the grounded theory to approach the issue. We focus on the state of Wisconsin, which has 365 farmers market and a rich history of farmers markets and direct producer sales. This study was conducted in the context of a multipronged statewide obesity prevention initiative, spearheaded by the University of Wisconsin Obesity Prevention Network and with support from the Wisconsin Partnership Initiative and the USDA-supported Ridge Center for Targeted Studies. The results from this paper will supply information on ways to overcome major barriers encountered by farmers markets around the nation that are interested in beginning a farmers market EBT program.

\section{Applied Research Methods}

To understand the different redemption practices for FoodShare dollars in farmers markets in the state of Wisconsin, in-depth interviews regarding the use of EBT were performed with 13 market managers. (FoodShare is the name given to the SNAP program in the state of Wisconsin.) The markets themselves were purposefully chosen to represent different geographic regions of the state, sizes, and years of operation. Markets were eligible if they report to the USDA Farmers Market Directory, reflecting approximately $84 \%$ of all farmers markets in Wisconsin (Roubal, 2015).

We contacted farmers market managers initially through email and then telephoned the following week to schedule an interview. We asked the managers to participate in a semistructured, qualitative interview regarding SNAP redemption at their market and to complete a structured questionnaire that collected basic sociodemographic and market characteristics. Interviews lasted approximately 1 hour and included multiple choice as well as open-ended questions. Participants could choose between completing the interview face-to-face or by telephone. They received a small incentive of a US $\$ 50$ gift card. The initial recruitment goal for the study was 10 markets redeeming SNAP using EBT and 5 markets not offering EBT, in order to obtain different perspectives. In total, 10 markets with EBT redemption programs in place and three without were interviewed. Lack of response from managers at markets without EBT was the main reason for the limited representation of this market type.

The lead investigator performed audiorecorded interviews. The recordings were transcribed by a third-party transcription service (using Caption Sync from Automatic Sync Technologies in Seattle, Washington). The interviewer also took field notes during each interview, which were included for analysis. Participants were asked questions about market demographics, history, employees, EBT, WIC redemption, environment, and other topics using a semistructured interview guide developed with the assistance of researchers in the departments of Population Health Sciences, Urban and Regional Planning, and Human Ecology at the University of Wisconsin-Madison (available upon request).

Qualitative interview data were analyzed using grounded theory analysis of the interview data (Grounded Theory Institute, 2014) to develop a general theory or theories for the topic, "Why is EBT accepted at some farmers markets but not at others?" No a priori theories as to why this occurred were utilized; instead, the interviewer privileged the perspective of the participants and sought to understand how they understood their circumstances. Grounded theory is an inductive methodology that is used to derive a theory from an evaluation of the available data. It allows for the development of conceptual categories and not one overall answer. As we suspected that the relationship of interest was complex, this method was used to analyze our interview data (Grounded Theory Institute, 2014). Grounded theory allows for the development of a theory, as opposed to the testing of a specific theory (Stern, 1980). It was the best fit as there is no generally accepted theory about why 
EBT is accepted at certain farmers markets but not others.

The analysis consisted of the three main steps for grounded theory analysis: coding and theorizing; memos and theorizing; and integrating, refining, and writing up theories. Selective coding was performed by coding portions of the interviews related to the core question. Coding was performed manually by the primary investigator due to the low count of interviews (13). We analyzed the transcriptions for recurring themes to identify reasons for EBT acceptance at farmers markets. We created and grouped memos into categories in order to develop theories as to why EBT redemption was successful at specific farmers markets in Wisconsin (Table 1). The research group reviewed general themes in discussions regarding the transcripts.

Preliminary results were presented at the annual Wisconsin Fruit and Vegetable Growers conference to a room (30 to 40 people) of farmers market managers across the state to perform member checking. Member checking is a useful way to validate findings in a range of research approaches; it consists of testing "data, analytic categories, interpretations and conclusions with members of those groups from whom the data were originally obtained" (Robert Wood Johnson Foundation, n.d., "Definition," para. 1). This study was considered exempt from institutional review board protocols by the University of WisconsinMadison.

\section{Results}

\section{Participant Characteristics}

Farmers markets participating in the study represented the geographic diversity of the state in terms of location and urbanicity. Two markets were located in southeastern, 5 in southcentral, 1 in southwestern, 2 in northwestern, 2 in west central, and 1 in central Wisconsin (Appendix).
Populations of the cities in which the participating farmers markets were located ranged from 8,391 to 599,164 (median=47,134) (U.S. Census Bureau, 2013). Markets ranged in size from 10 to 160 vendors (median $=50)$. EBT initiation at the 10 markets that had already implemented it occurred between 2008 and 2014 (Appendix).

\section{Factors Associated with EBT at Farmers Markets}

\section{Interest}

EBT redemption required that farmers markets had certain conditions in place. First, an interest in allowing SNAP funds to be redeemed at the market was necessary. This interest may have been generated by the community, the market mangers and/or vendors, or an outside source. Markets with or without EBT redemption acknowledged that food security was formally or informally a part of their markets' mission. Most farmers markets' mission statements included terms regarding "local produce," "healthy," and "access." For example, the Milwaukee County Winter Farmers' Market mission statement includes "equitable access to whole foods" (Milwaukee County Winter Farmers' Market, n.d., "About MCWFM," para. 1). One market mentioned redefining its mission statement to include food access issues; adding this statement made it easier to talk with public health departments, businesses, and other agencies to build partnerships. Several market managers mentioned having an interest in redeeming the funds and researching EBT after having been approached by a local city or health department that offered to provide funds for obtaining the machine. As one market manager noted, 
The market had been interested in doing [EBT] for a little while...I started the application process to become a SNAP retailer...It felt like we were waiting to see if anything was going to come about and we basically said..." "we're just going to commit to funding our own anyway." We felt like that was in line with our mission... and then very fortuitously, we got approached by the state of Wisconsin Department of Health and Human Services to participate in this grant, and we got some funding to help purchase the equipment.

Market managers are busy with multiple activities, so adding an EBT machine or changing redemption procedures is a process that can unfold over months or years. Leadership is important in this regard: some leaders perceive and act on an EBT redemption system as a mission of their market, while other managers perceive a different mission and deploy their scarce resources in different ways, or act on different priorities.

\section{Financing}

Financing the EBT machine was a barrier common across markets. Three markets received funding from either the city in which the market is located or the organization that operates the market (Appendix). The machine usually costs around US $\$ 1,000$ (Illinois Department of Agriculture, 2009). Additionally, the market must have a plan in place to pay the wireless and transaction fees. According to market managers, the monthly wireless fee dominated these costs at around US $\$ 45$ per month; the fee per EBT transaction was about US $\$ 0.15$. One market manager indicated, "The monthly wireless cost dominates the cost to run the machine. The transaction fees are minute, but if I have to turn on the machine for one person per month then it gets difficult to justify the service." To get past this financial challenge most markets received assistance for EBT costs through grants, local nonprofit organizations, city governments, or health departments. The Dane County Farmers Market (DCFM) received financing from the city of Madison for its EBT program. The bookkeeping functions were performed by a local nonprofit organization, the Community Action Coalition. The markets in Beloit and Green Bay received funding for their EBT programs from the organizations that support the markets, Downtown Beloit Association and Downtown Green Bay, respectively. Both organizations acknowledged that the cost of the program is high, but that they do not anticipate support for the program to disappear.

Three of the markets received external funding for their EBT programs from an agency not associated with the market itself. The Westside Market in Madison, Wisconsin, was awarded a "Transformation Grant" from the Department of Health Services that had money earmarked for food access issues. The market manager noted that the market had already begun discussions regarding how to implement EBT in the market, "and then very fortuitously, we got approached by the State of Wisconsin Department of Health and Human Services to participate in this grant, and we got some funding to help purchase the equipment." Positive aspects of the grant funding were that EBT could accepted with no cost to the market or community, and it was a fairly fast way to obtain the machines and tokens necessary to begin the EBT program. A limitation of the grant funding was that the sustainability of the EBT program was questionable unless another funding source could be identified. The market also needed to have someone on staff capable of grant-writing or forming relationships with government agency staff who could assist with this task.

The Cameron Park Market in LaCrosse tried an innovative method to defer EBT costs. They were the only market in the sample, at the time of the study, to allow EBT transfers using debit cards. Although measures of cost-effectiveness were not yet available, the market manager remarked on positive responses from vendors and customers. The market charged a small fee to cover the transaction, which in turn helped cover the cost of the SNAP transactions done using the same terminal.

\section{Paperwork}

There were two types of paperwork to initiate the program once interest was generated and markets made the decision to adopt EBT. First, the proper 
paperwork needed to be completed to be granted a USDA FNS identification number for tax purposes. In most cases the markets themselves applied to be an EBT vendor, but in one case vendors within the market applied to have their own EBT identification numbers. Most markets apply instead of vendors because it reduces the amount of paperwork required.

Second, market management had to incorporate administrative tasks into their routine. Often this involved some paperwork; for instance, the DCFM had to establish an agreement with the local organization Community Action Council (CAC) to do bookkeeping for SNAP transactions on a weekly basis. Following that negotiation, the market and CAC signed an agreement regarding the actual transfer of information, records to be kept by CAC, and payment to vendors for the money earned in SNAP/EBT sales. For some markets these partnerships were already in place, relationships were strong, and partners were willing to bear the administrative burden, which made the process easier for market management. In other situations the administrative burden and/or the absence of willing partners inhibited participation in EBT transactions.

\section{Training}

Once an EBT machine was functional and financed, the market needed to decide how to perform the redemption on market day. Markets trained volunteers or employees on how to operate the EBT machine. Occasionally partners participated in the training. In smaller markets the farmers market manager typically assumed this role. However, in larger markets the EBT machine was operated by volunteers. This included swiping the EBT cards and providing the tokens or vouchers for redemption at the vendor stalls. At the end of the market day, a volunteer or often the market manager went around to all market vendors and recorded the number of tokens redeemed at each vendor, the most common mechanism for collecting EBT payments by customers. In one case this process also included payment to the vendors.

Our data indicate that, like interest in EBT, training in its use develops over time in processes that incorporate new experiences, and markets occasionally find support in partner organizations. For instance, in the La Crosse market the manager noted that, "we do a training at the beginning of the season... It consists of me going around and speaking with them [vendors]." However, the manager notes difficulties in training non-English speakers, "Honestly, the one place where we have a gap, I think, is, our Hmong vendors because there's a little bit of a language barrier. But a lot of times there will be somebody else working with them that has better English, like a second generation [vendor] or something, that we can speak to really easily, but because their family operations, there's lot of times people working." This manager identified a need for training, but also went on to show how partners can help supply training, saying, "Last year, for the first time though we had someone from the Health Department speak, so she even helped us do the training. And I think next year I kind of want to do that again just because we do have a couple new vendors and it's always good to make sure they understand exactly." These data illustrate how market managers are responsive to opportunity and sensitive to the needs of their vendors. Appreciating the multiple processes in place is an important element of understanding adoption and practice of EBT in markets.

\section{Reimbursement Processes}

Reimbursement of market vendors, another aspect of financing, was also cited as a barrier. Tracking and reimbursing payments requires substantial bookkeeping. Most markets reimbursed vendors biweekly or monthly to eliminate the number of checks written. As the Cameron Park manager noted, "This year we're doing every other week redemption... But it is hard [for vendors to wait]." This market previously reimbursed every week, but was spending a large sum to purchase checks. Some markets additionally required a minimum number of tokens for a check to be written (e.g., US $\$ 10.00$ ) so that the cost of ordering blank checks did not outweigh the benefits of the program. In contrast, the Oshkosh Saturday Farmers Market, a year round, large market located in northeastern Wisconsin, currently has volunteers who reimburse vendors daily. Vendors generally 
prefer to be reimbursed on market day for the product they sold. While the time intensity for reimbursement and the cost of blank checks makes this difficult, after a few cycles of redemption market managers noted more positive feelings and vendor trust toward the redemption process and greater support for the program overall.

Market managers also mentioned difficulties with token swapping, where tokens "purchased" at market "A" were redeemed at market "B." This happened when several markets with EBT redemption were located close together. This exchangeability of EBT tokens occurs because the EBT stamp is on one side of the token, but during the transaction the vendor may not look at the other side, which indicates at which market the EBT reimbursement occurred. Market managers suspected that this is an informal market system occurring from vendor to vendor rather than customer to vendor, but still creates an issue for the market because they are not able to reimburse the vendor if they do not turn in the tokens unique to the market at which they are vending. This problem is exacerbated because tokens purchased on one day can be redeemed during later weeks, and market managers often noted that the EBT amount swiped rarely equals the amount redeemed that day. This makes it difficult to balance the books during weekly farmers market hours.

Market managers, however, have mixed impressions about the difficulties presented by this situation. At the Dane County Farmers Market, the cost CAC imposes to handle transactions is of more concern to management then the burden on vendors from having to wait for that portion of their sales. According to the market manager, "the Community Action Coalition handles all of the bookwork. They send out checks once a month. You know, which was a bit of an adjustment for the members [who asked] 'What, you mean we're not going to get cash right away?" The proportion of income earned from EBT was relatively small, and vendors grew accustomed to waiting. From the manager's point of view, negotiating with and paying CAC was the chief problem: "you know, funding is an issue. Funding the operation is probably the biggest challenge."

This returns us to the questions of relationships with the market's community and its community partners. Managers reported that another challenge farmers markets face when implementing EBT is the distinction between debit cards and EBT cards. Some markets use tokens for both EBT and debit card transactions, and these must be separated due to the rules on products that can be purchased with EBT funds. This must all be tracked for an accountant to reconcile later in the week. This is often the farmers market managers' duty in small markets, but for large markets the accounting function is contracted out to volunteers or local businesses. For instance, DCFM, the large market that contracted with CAC, said, "we have given some money to Community Action Coalition to kind of keep things going and keep things afloat. We had kind of a tough situation earlier this summer because they-they wanted money. And we were like okay, that's fine but we need to see documentation to see where it's going. It got a little dicey. We said we're not going to give you money until you show us documentation. They're like, 'we're working on it.' And then the city and the county came along with a grant." Again, this quotation reveals how ongoing relationships are both sources of concern and support to market managers.

\section{Obtaining Compliance from Vendors}

Every market, with one exception, mentioned the challenge of obtaining compliance from all eligible vendors. Market managers provided examples of political opposition or language barriers when describing why this opposition to the EBT program occurred. For example, in the case of Hmong or Hispanic vendors, "there's a little bit of a language barrier. But a lot of times there will be somebody else working with them that has better English, you know, like a second-generation [vendor] or something, that we can speak to really easily." This quotation from training was important for interaction with customers using EBT tokens as well. Farmers market managers reported that some vendors equate the EBT program with "government handouts" and thus refuse to accept transactions from these customers. Additionally, many Wisconsin farmers market vendors are Hmong or Hispanic, meaning that their primary 
spoken language is not English. This makes it difficult to understand the entire EBT process or ask questions when the process is unclear. A few markets have added board members who are fluent in both languages to reduce these barriers. The bilingual board members often translate important documents as well as translate during meetings for vendors in order to assure understanding of and compliance with market rules and EBT redemption procedures. They are also available to assist customers when necessary on market day.

\section{Advertisement}

A challenge mentioned by all market mangers, some when prompted, was the need to advertise the fact that EBT is accepted in order to obtain a larger customer base and maximize profits for the vendors and leverage the cost of the wireless fee. The farmers market managers had tried several marketing tactics. Most made note of EBT acceptance on all their press releases, Facebook pages, websites, newsletters, and flyers. However, others obtained support from the local health department, community centers, and even local grocery stores to target advertising to individuals already redeeming their SNAP benefits, but who are not doing so at the farmers market. One market manager expressed how the market had targeted areas of the community to publicize EBT, "So this year we sent out a letter to all of the churches in the area, not just [our area] but kind of the county and surrounding communities. We delivered posters to some of our lower-income facilities. We're trying to get the word out as much as possible." Successful marketing campaigns bolstered the number of customers and volume of transactions each week.

\section{Community Support}

Markets with EBT programs maintained strong community ties that provided help in the way of advertising, funding, staffing, marketing, and grant writing. The Milwaukee County Winter Farmers' Market has partnered with the Hunger Task Force and Indian Health Center to help promote its market, the acceptance of EBT funds at the market, and its additional US $\$ 20$ voucher program. Other markets have partnered with local health departments, grocery stores, and state agencies to promote the fact that their market accepts EBT. Managers at three of the 10 markets operating EBT reported partnering with local nonprofit organizations that assisted in everything from financing the EBT machine to facilitating redemption. The market in Plymouth, Wisconsin, partnered with United Way to cover the costs associated with the machine. As the market manager stated, "Well, we decided that we wanted to do it... Then we approached United Way and they went, 'Of course.' They got the money for us to put the machine in and now they support us in the market every year to pay for any of the fees." We are not surprised that market managers have developed partnerships with government and business in order to foster vendor success.

Likewise, the Stevens Point Farmers Market was able to implement the EBT program with the support of the Central Rivers Farmshed, which received a Centers for Disease Control grant to operate EBT at two local markets. The Milwaukee County Winter Farmers' Market has supported EBT for many years and was the only market in the city until the 2014 season to do so. A staple of its winter program was a match of US $\$ 20$ in EBT funds, which increased marketing through EBT participants' word of mouth and thus increased vendor sales. The funds for this program and the EBT machine came from the Farmers Market Promotion Program, a USDA program to increase direct producer-to-consumer market opportunities (USDA AMS, n.d.). Another noteworthy example of a market receiving assistance with EBT redemption is the MadMarket Double Dollars program in which the city of Madison partnered with CAC and local businesses to provide more tokens for individuals redeeming their EBT funds at four farmers markets in Madison. Customers who used EBT at the markets received double the amount they were allowed to spend, up to US $\$ 25.00$. Partnerships with cities or organizations were very helpful in garnering support for EBT programs. Benefits of these partnerships were that there are numerous connections involved, such as local businesses, that can also be approached for support.

The Oshkosh Saturday Farmers Market partnered with two local Rotary International organizations to operate its EBT redemption 
program. Volunteers from Rotary International assist in staffing the EBT redemption booth and reimbursing vendors on market day. The Central Rivers Farmshed provided the staffing and financial support for EBT redemption at the Stevens Point Farmers Market. Successful cooperation and mutually beneficial relationships between market managers, the market vendors, advisory leadership teams, and the organization led to successful EBT redemption in all of these markets.

\section{Barriers to EBT Adoption Among Markets Without Acceptance Programs}

Among the three market managers interviewed whose markets did not accept EBT, three themes emerged. First, the small market size led to concern over the volume of EBT transactions the market could produce. All the markets in our study that did not have an EBT program had fewer than 30 vendors. The cost of obtaining the EBT machine and the anticipated operational costs were not perceived to be worthwhile to the markets at the current time because their customer demand was low. Second was the amount of work required. At smaller markets the manager often works only part-time. When a manager is only paid to spend 10 hours per week or less on market work, it is difficult to find time to perform other duties. The market day itself often required six or more hours, leaving little time for other duties. Third, most of the market vendors already accepted WIC. Although SNAP was not accepted through EBT at these markets, another form of federal nutrition assistance, WIC, was accepted at the market and the market managers felt that they were partially meeting the demand. As one market stated, "The vendors accept WIC, we know it is not the same, but at least it's something."

Perhaps most promising, all the managers whose markets did not have EBT yet expressed a desire to accept EBT in the future. They agreed with the premise of the program and the potential it has to improve food security. However, they expressed that, at the time of the interview, the costs did not justify the benefits. A market manager summarized all these issues as shown in this quotation: "And it's just the two of us, and I'm part-time. So we can't make it work, but I wish we could."

\section{Member Checking}

Data and results from the study were presented in an hour-long presentation to the Wisconsin Farmers Market Association at the Wisconsin Fresh Fruit and Vegetable Growers Conference on January 26, 2015. This activity provided an opportunity to summarize the preliminary study findings and receive feedback from a larger set of farmers market vendors and managers. The results of the member checking generally supported the interpretation of the interview data and the themes identified as related to EBT implementation or lack thereof. Member checking validated the importance of the subcategories. Agreement was very strong with the relevance of having a motivated market manager, with many unsolicited comments regarding individuals who took time when they were "off the clock" to work to obtain an EBT machine for their market. Additionally, the importance of community partnerships was supported and new examples were provided, such as a hospital that is working to partner with farmers markets to provide "gift certificates" for fresh fruit and vegetable baskets for patients at or below the federal poverty line. EBT operational issues were also agreed upon by the audience, especially in regards to how to reimburse vendors. Markets that perform direct deposit described their methods to reimburse vendors weekly and avoid the nuisance and costliness of ordering checks.

\section{Discussion}

To understand some of the barriers to offering EBT at a farmers market, we investigated factors associated with implementation of EBT redemption systems at farmers markets using grounded theory analysis. From the farmers market manager interviews, the major themes of interest, training, advertising, community support, and having a motivated market manager were identified as important facilitators for both initiating and sustaining a successful EBT program. Overcoming financial barriers, paperwork, reimbursement methods, and enforcing vendor compliance were identified as barriers to implementing and sustaining an EBT program. We believe our findings can be summarized as providing a deeper understanding of the processes market managers interweave 
and navigate in the course of establishing an EBT program.

The acceptance of nutrition assistance benefits through EBT at farmers markets is an emerging research area. It has the potential to positively affect consumers, vendors, markets, and communities. Although the program was established nationally in 2002, EBT is still not offered at all farmers markets. Market managers, vendors, and community organizations are now realizing the potential benefits of accepting SNAP through EBT. Vendors and market managers often see EBT as a new revenue stream. They may also see EBT as a way to improve community food security and a way to get fresh, healthy fruits and vegetables to low-income individuals.

Our study suggests that although markets often have their own unique nuances to EBT redemption, the themes of the challenges and facilitators are consistent across the markets sampled. Characteristics of the challenges to and facilitators for EBT redemption at markets were explored through grounded theory analysis. Having community support, finding strategies to successfully deal with operational issues, having motivated market mangers, and having a mission statement inclusive of food security were identified as factors that had contributed to successful EBT implementation. These themes encompass those identified with positive feelings about EBT from a recent study performed in Michigan (Montri, Behe, \& Chung, 2013). This study indicated that ease of reimbursement and a low administrative burden for vendors, along with the belief that accepting food assistance increased their customer base, were associated with positive feelings toward EBT. These themes fit under operational issues in our study. These results indicate that the themes identified in the study may be generalizable to other areas of the U.S. Difficulties with and strategies to obtain funding, marketing, and positive support were expressed repeatedly as barriers by study participants; this agrees with findings reported by previous literature (Cole, 2013; Farmers Market Coalition, 2016; Krokowski, 2014; Payne, Wethington, Olsho, Jernigan, Farris, \& Walker, 2013). Funding has remained a challenge for EBT redemption because of the high up-front costs associated with this program. Marketing remains a problem in that many individuals who receive SNAP funds are not aware they can use them at the market. Our finding of the role of the mission statement and its positive influence on the move to adopt EBT is a novel contribution of our study. An interest in improving food security was noted in a study performed in San Francisco markets (Jones \& Bhatia, 2011), but there was no direct mention of a mission statement. However, Wholesome Wave recommends examining a market's mission statement as one of the first steps to determining if a market is ready to implement EBT (Owens \& Verel, 2010). Future research should investigate the role of this factor and consider it as a potential strategy to increase interest in EBT adoption at farmers markets.

No two markets were alike in their approach to EBT funding, yet several markets developed successful mechanisms for EBT redemption. Markets continue to change their EBT redemption practices to streamline the process and increase the dollar amount redeemed. Identifying and understanding the similar, yet unique, challenges that farmers markets face when implementing an EBT program can help new markets or markets considering changing their practices to improve their redemption process. Farmers markets should assess each method to determine which method or combination of methods will work best based on their own unique needs.

In light of all the different methods undertaken by farmers markets to redeem FoodShare benefits in this small sample in Wisconsin, it is clear that no one-size-fits-all prescription for EBT redemption at farmers markets exists. Each market must do what fits the organization itself with regards to financing and operation. Farmers markets have successfully implemented EBT programs through both grant funding and community support. They have also been successful with reimbursing vendors daily, monthly, or on some schedule in between. This process is completely dependent on the needs of the market, its managers, and its vendors.

The ability for markets to design unique reimbursement programs in order to overcome barriers to the redemption of federal SNAP dollars 
is not unique to Wisconsin. Farmers markets across the U.S. are designing their own programs to maximize the SNAP funds redeemed. In Arizona, simply providing EBT machines to farmers markets resulted in an increase in SNAP redemption and overall market spending in $80 \%$ at the markets (Bertmann, Ohri-Vachaspsati, Buman, \& Wharton, 2012). The Philly Bucks Program in Philadelphia, an intervention that provided US $\$ 2.00$ incentives which could be redeemed for fruits or vegetables at a farmers market, showed an increase in SNAP redemption up to 5 times higher than before the intervention (Young et al., 2013). A program in Nashville, Tennessee, brought a farmers market into a low-income neighborhood and awarded students and adults "Super Shopper" status for completing surveys, which translated into vouchers for the market (Freedman, Bell, \& Collins, 2011). The market gained new customers and had a high retention rate of those new customers. A study in North Carolina identified the most important reasons for EBT use at farmers markets as being able to use nutritional assistance dollars, having transportation, and knowledge of market's operational hours (Leone et al., 2012). While these studies are mostly from the users' perspectives, they highlight two important points with regards to users. First, not accepting SNAP is a major reason for individuals not visiting farmers markets, and second, individuals with SNAP benefits are often unaware they can be used at farmers markets that accept EBT. These results are promising in encouraging continued implementation of EBT at farmers markets around the country. In early 2015, the Farmers Market Coalition announced that through a partnership with USDA FNS, EBT equipment will be provided to farmers markets for up to 3 years. This lifts some of the burden off the markets themselves to initiate the program and make it economically viable in the first few years (Farmers Market Coalition, 2015).

All market managers noted that EBT was a major undertaking. Most agreed that it required half a market season to work out all the nuances associated with the machine and reimbursement. However, once the program was underway, all the market managers noted that it worked well and they would continue doing it. Expending the time and energy needed to implement an EBT program and then sustain it are truly commendable when considering all the issues that must be overcome in order to operate a successful EBT program.

This paper highlighted some of the mechanisms used to successfully overcome barriers to EBT implementation and some of the positive and negative aspects associated with the overall process. This is one of the first studies to attempt to identify issues that the farmers market has in implementing an EBT redemption program, and the first to do in-depth interviews with specific markets with open ended questions. A grounded theory approach was used in order to synthesize the data available from all interviews performed. Grounded theory allows for studying participants' meanings, intentions, actions, and situations. In addition it allows for the study of diverse processes and relationships between individuals and the process (Charmaz, 2003), in this case market managers and SNAP/EBT redemption. Instead of generating a list of over 20 strategies for how farmers markets can operate SNAP/EBT effectively, it allows for synthesizing the data using memos, thus strengthening the results by providing examples of the major themes and concepts identified (Charmaz, 2003). Grounded theory also allows for researchers to check the concepts and theories that were developed with new sets of data or others interested in the topic through member checking. For these reasons grounded theory was used over other qualitative methods, such as narrative research, phenomenological research, ethnography research, or case study research. Narrative research, ethnography, and case study research all focus on the unit of analysis of a single individual (Creswell, 2013). Phenomenological research is used to understand how individuals perceive a process (Lester, 1999). Phenomenological research would have been used if the research team interviewed farmers market customers, EBT operators, market manager, and farmers market board members, for example, to synthesize the perceptions of this diverse group of individuals who interact with the EBT process. Although the research team was interested in the stories told by the market manager (narrative), the cultural context of the market (ethnography), and 
the experience of the market manager (phenomenological), grounded theory allowed the research team to combine all these elements to answer the essential question.

Much of the work related to EBT redemption has been on barriers to use by those receiving SNAP benefits (Berzins, 2004; Colasanti, Conner, \& Smalley, 2010; Dixit-Joshi, Burke, Das, \& Williams, 2014; Flamm, 2011; Grace et al., 2007; Kaye, Lee, \& Chen, 2013; Payne et al., 2013; Wetherill \& Gray, 2015). Social stigma, unnecessary burden, higher perceived cost of produce, and lack of knowledge about EBT acceptance at farmers markets were identified barriers to using SNAP at farmers markets from the beneficiaries' point of view (Colasanti et al., 2010; Dixit-Joshi et al., 2014; Kaye et al., 2013; Wetherill \& Gray, 2015). In order to implement SNAP/EBT successfully, interventions must be designed with the involvement of market managers, vendors, and consumers. Studies on facilitators to successful EBT from a farmer/ vendor perspective include promotion of program, increased sales, and satisfaction with program design (Krokowski, 2014; Oberholzer, Dimitri, \& Schumacher, 2012). Yet little work has been performed on understanding barriers from the farmers market's perspective. This paper fills this void and should serve as a starting point for more research. From a public health perspective, this paper serves to identify several of the barriers to EBT redemption that exist across most farmers markets.

\section{Strengths and Limitations}

This study has several strengths. This was the first study, to our knowledge, to provide a deeper investigation into reasons for successful EBT redemption methods in farmers markets. The qualitative nature of the interviews allowed for each farmers market manager to tell a narrative for his or her market, allowing for the identification of themes not previously researched. Finally, these interviews included farmers markets from all across the state and markets of many different sizes, as well as markets without EBT redemption methods, allowing for a wide range of issues with EBT to be explored.

\footnotetext{
${ }^{1}$ http://www.vfmma.org/instructional/snapebt-tool-kit
}

There are also limitations of this analysis. This study was limited to farmers markets in Wisconsin. The sample size was small (13) due to the in-depth and time-intensive nature of the on-site interviews. This number and the overall participation rate of $57 \%$ (13 of 23 markets) was similar to other qualitative studies in which interviews were conducted, rather than limiting the study to online surveys (Hasin et al., 2014; Krokowski, 2014; Ward et al., 2015). In performing member checking it became apparent that many other EBT redemption methods, outside the 13 markets interviewed, occur in the state and were not included in this study (e.g., weekly direct deposit to vendors for EBT tokens). Additionally, this study focused on barriers to EBT redemption by the farmers markets themselves. It did not include information on consumer-focused issues which might enhance or detract from participation with farmers markets or EBT. This dynamic relationship between consumers, vendors, markets, and SNAP should be further explored. Furthermore, we were only moderately successful in recruiting managers from markets that have not implemented EBT for our study. Further research should find strategies to include the voice of these markets, as they can provide additional insights regarding barriers to EBT adoption.

\section{Recommendations}

From the managers' narratives, some lessons regarding effective strategies to implement EBT can be drawn. Additional resources provided by markets currently operating an EBT machine would be useful for markets that have not been able to implement EBT transactions. Tool-kits such as the one provided by the Virginia Farmers Market Association " (n.d.) as well as some "lessons learned" of successes and failures from other markets would be useful for market managers either initiating or struggling to maintain an EBT redemption program. The most important strategy uncovered is connecting the farmers market to other community sectors, such as business, government, nonprofit, clinical care, and public health. Through partnerships with these organizations, markets can receive assistance with 
promoting and marketing the farmers market and EBT that will help attract new customers, finance the cost of EBT, operate the machine, and increase staffing to run EBT operations smoothly. Covering the cost of EBT could include a broad range of financial help, from providing incentive programs for EBT users, helping apply for grants to cover the cost of the machine, or providing funds to cover the cost of the machine or internet fees. Additionally, individuals from these sectors might help operate the machines and perform the paperwork for the farmers market. Building these community partnerships assists with operational issues of EBT.

The largest barrier to EBT redemption according to this research is financing the machine. This barrier was noted in all interviews. Through community and business partnerships the machine can be financed and operated successfully, as exemplified by many markets in this study. Having programs that funding the machine and pay for the monthly wireless fee is especially important for markets new to EBT. The removal of costs might persuade them to try EBT at their farmers market if they do not have to accrue any immediate implementation costs. These recommendations can be applied to other nutrition assistance programs such as WIC and SFMNP. Although those programs still operate using paper vouchers, they will imminently be transitioning to EBT type redemptions.

There are many recommendations for future research and policy as well. Researchers should investigate how to best market the EBT redemption program at farmers markets to increase the volume of EBT transactions. This work might focus on where the advertising should be located, who should be responsible for the advertising, what methods are most successful, and how new customers are obtained, as well as how likely customers are to return. Simply adding an EBT machine at a market will not immediately remove the barriers to accessing healthy food. However, it is one step in the process. Research must be conducted to identify characteristics of SNAP beneficiaries who currently shop at farmers markets, and then interventions must be designed to attract new customers to the market to improve the number of EBT redemptions. Market research is also needed on the sustainability of EBT at markets. Market size and the cost of the machine versus the volume of transactions may play important roles in a farmers market's decision to implement or continue EBT in the future. Additional research should focus on location of farmers markets and redemption practices. Very preliminary work from our study suggested that in Wisconsin, census tracts with farmers markets were more likely to be categorized as a food desert compared to census tracts without farmers markets. This is contrary to current theories, as farmers markets are believed to be located in wealthy areas where food insecurity is not an issue.

Two additional analyses are proposed. First, a study of EBT redemption at farmers markets and their census tract demographic characteristics (percentage of population receiving SNAP, percentage minority, etc.) across the U.S. should be conducted to determine if EBT is being located where it is of most need. Second, researchers should perform a cost-benefit analysis on a random sample of farmers markets across the U.S. in order to determine how to best maximize the program. Finally, policy implementation must follow the results of this study, the former studies, and the suggested studies. San Francisco mandated that all farmers markets accept SNAP funds through EBT (Jones \& Bhatia, 2011). However, this policy has community support and a reliable funding source. Such benefits might not be available to all markets. Thus EBT is promoted at farmers markets, but more research is needed to understand the true cost and social and health impacts of the program.

\section{Conclusion}

Farmers markets have the potential to reduce food insecurity and improve access to healthy foods among economically disadvantaged populations. However, to date access remains limited by the small percentage of markets in low-income neighborhoods that accept SNAP benefits through EBT. Understanding the main barriers as well as effective strategies for successful implementation of EBT in farmers markets is imperative to realize the full potential of these outlets. There are many challenges to EBT acceptance for farmers markets, related mostly to cost, operational logistics, and 
ensuring sufficient demand. Community partnerships can assist markets with obtaining funding, establishing operating procedures, and marketing. Motivated market managers and a mission statement targeted toward food security also facilitate adoption and maintenance of EBT. Finding ways to streamline redemption and reimbursement procedures is an important challenge. Strategies vary across markets and must match the needs of each market and the community it serves. Policies and programs to remove barriers to EBT implementation and resources to promote sharing of successful stories are warranted. Further research into understanding the various processes associated with establishing EBT is also warranted. We believe that each market has a particular story to tell about these interwoven processes; however, we also believe that similarities can be discerned in different markets, and these need to be understood and described in order to make other, more general policies and recommendations that market managers can follow.

\section{Acknowledgements}

The authors acknowledge funding from the USDA RIDGE doctoral dissertation program. The authors also extend immense gratitude to the farmers market managers interviewed for this study. The authors would further extend acknowledgement to Dr. Bridget Catlin, Dr. Kristen Malecki, and Dr. Ronald Gangnon, who provided comments on drafts of this manuscript.

\section{References}

Ammerman, A. S., Lindquist, C. H., Lohr, K. N., \& Hersey, J. (2002). The efficacy of behavioral interventions to modify dietary fat and fruit and vegetable intake: A review of the evidence. Preventive Medicine, 35(1), 25-41. http://dx.doi.org/10.1006/pmed.2002.1028

Anderson, J. V., Bybee, D. I., Brown, R. M., McLean, D. F., Garcia, E. M., Breer, M. L., \& Schillo, B. A. (2001). 5 a day fruit and vegetable intervention improves consumption in a low income population. Journal of the American Dietetic Association, 101(2), 195-202. http://dx.doi.org/10.1016/S00028223(01)00052-9
Anliker, J. A., Winne, M., \& Drake, L. T. (1992). An evaluation of the Connecticut Farmers' Market coupon program. Journal of Nutrition Education, 24(4), 185-191. http://dx.doi.org/10.1016/S0022$\underline{3182(12) 81152-6}$

Balsam, A., Webber, D., Oehlke, B. (1994). The Farmers' Market Coupon Program for low-income elders. Journal of Nutrition for the Elderly, 13(4), 35-42. http://dx.doi.org/10.1300/J052v13n04 05

Bertmann, F. M. W., Ohri-Vachaspati, P., Buman, M. P., \& Wharton, C. M. (2012). Implementation of wireless terminals at farmers' markets: Impact on SNAP redemption and overall sales. American Journal of Public Health, 102(7), e53-e55. http://dx.doi.org/10.2105/AJPH.2012.300727

Berzins, A. (2004). Farmers' markets in low-income communities in L.A. County: Assessing needs, benefits and barriers, with a focus on the shift to electronic benefit transfer technology for food stamp recipients. Urban and Environmental Policy Institute, Occidental College. Retrieved from http://www.occidental.edu/urbanenvironmental-policy/our-students/past-comps

Bollen, C., Vernez-Moudon, A., Kinney, K., \& Drewnowski, A. (2010). How farmers markets can promote access to healthy food: A look at how population groups and farmers markets interact. University of Washington Center for Public Health Nutrition. Retrieved from http://depts.washington.edu/ uwcphn/pubs/reports.shtml

Briggs, S., Fisher, A., Lott, M., Miller, S., \& Tessman, N. (2010). Real food, real choice: Connecting SNAP recipients with farmers markets. Community Food Security Coalition and Farmers Market Coalition. Retrieved from http://cclhdn.org/wp-content/uploads/ 2013/02/RealFoodRealChoice_SNAP_Farmers Markets.pdf

Brown, A. (2001). Counting farmers markets. Geographical Review, 91(4), 655-674. http://dx.doi.org/10.2307/3594724

Brown, C., \& Miller, S. (2008). The impacts of local markets: A review of research on farmers markets and community supported agriculture (CSA). American Journal of Agricultural Economics, 90(5), 1298-1302. http://dx.doi.org/10.1111/j.1467$\underline{8276.2008 .01220 . x}$ 
Buttenheim, A., Havassy, J., Fang, M., Glyn, J., \& Karpyn, A. E. (2012). Increasing supplemental nutrition assistance program/electronic benefits transfer sales at farmers' markets with vendoroperated wireless point-of-sale terminals. Journal of the Academy of Nutrition and Dietetics, 112(5), 636-641. http://dx.doi.org/10.1016/j.jand.2011.12.021

Centers for Disease Control and Prevention. (2013). Addressing obesity disparities: Cultural competence. Atlanta: Author.

Charmaz, K. (2003). Grounded theory. In J. A. Smith (Ed.), Qualitative psychology: A practical guide to research methods (pp. 81-110). London, United Kingdom: Sage Publications.

Colasanti, K. J. A., Conner, D. S., \& Smalley, S. B. (2010). Understanding barriers to farmers' market patronage in Michigan: Perspectives from marginalized populations. Journal of Hunger and Environmental Nutrition, 5(3), 316-338. http://dx.doi.org/10.1080/19320248.2010.504097

Cole, K. (2013). Increasing access to farmers markets for beneficiaries of nutrition assistance: Evaluation of the Farmers Market Access Project. Preventing Chronic Disease, 2013(10), 130121. http://dx.doi.org/10.5888/pcd10.130121

Cresswell, J. W. (2013). Research design: Qualitative, quantitative, and mixed methods approaches (4th ed.). Thousand Oaks, California: Sage Publications.

Dixit-Joshi, S., Burke, J., Das, B., \& Williams, E. S. (2014). Facilitators and barriers for direct marketing farmers and farmers markets to participating in SNAP: Findings from the Farmers Market Operations Study. 142nd APHA Annual Meeting and Exposition. Retrieved from http:/ /www.researchgate.net/ publication/266777726_Facilitators_and_Barriers for_Direct_Marketing_Farmers_and_Farmers_ Markets to Participating in SNAP Findings from the Farmers Market Operations Study

Evans, A., Jennings, R., Smiley, A. W., Medina, J. L., Sharma, S. V., Rutledge, R.,...Hoelscher, D. M. (2012). Introduction of farm stands in low-income communities increases fruit and vegetable among community residents. Health and Place, 18(5), 11371143. http://dx.doi.org/10.1016/j.healthplace. $\underline{2012.04 .007}$

Farmers Market Coalition. (2015). FMC's free SNAP EBT eqquipment program. Retrieved from http:// farmersmarketcoalition.org/programs/ freesnapebt/

Farmers Market Coalition. (2016). SNAP at Farmers Markets Growing, but Limited by Barriers. Retrieved from https:/ / farmersmarketcoalition.org/snap-atfarmers-markets-growing-but-limited-by-barriers/

FitzGerald, E. A., Frasso R., Dean, L. T., Johnson, T. E., Solomon, S., Bugos, E.,...Cannuscio, C. C. (2013). Community-generated recommendations regarding the urban nutrition and tobacco environments: A photo-elicitation study in Philadelphia. Preventing Chronic Disease, 2013(10), 120204. http://dx.doi.org/10.5888/pcd10.120204

Flamm, L. J. (2011). Barriers to EBT use at farmers' markets: Lessons in empowerment evaluation from rural Ohio. Journal of Hunger and Environmental Nutrition, 6(1), 54-63. http://dx.doi.org/10.1080/19320248.2011.549801

Food Trust for Transform Wisconsin. (2014, September 23). Implementing a coupon incentive program [Webinar]. Available at http://fyi.uwex.edu/cfsi/ files/2013/03/FM-Incentive-webinar-slides-9-2314.pdf

Freedman, D. A., Bell, B. A., \& Collins, L. V. (2011). The Veggie Project: A case study of a multicomponent farmers' market intervention. The Journal of Primary Prevention, 32(3-4), 213-224. http://dx.doi.org/10.1007/s10935-011-0245-9

George, D. R., Kraschnewski, J. L., \& Rovniak, L. S. (2011). Public health potential of farmers' markets on medical center campuses: A case study from Penn State Milton S. Hershey Medical Center. American Journal of Public Health, 101(12), 2226-2232. http://dx.doi.org/10.2105/AJPH.2011.300197

Govindasmy, R., Italia, J., \& Adelaja, A. (2002). Farmers' markets: Consumer trends, preferences, and characteristics. Journal of Extension, 40(1), 1RIB6. Retrieved from http://www.joe.org/joe/2002february/rb6.php

Grounded Theory Institute. (2014). What is grounded theory? Retrieved from http://www.groundedtheory.com/what-is-gt.aspx

Grace, C., Grace, T., Becker, N., \& Lyden, J. (2007). Barriers to using urban farmers' markets: An investigation of food stamp clients' perceptions. Journal of Hunger and Environmental Nutrition, 2(1), 55-75. http://dx.doi.org/10.1080/193202408 $\underline{02080916}$ 
Gustafson, A., Lewis, S., Perkins, S., Wilson, C., Bucker, E., \& Vail, A. (2013). Neighbourhood and consumer food environment is associated with dietary intake among Supplemental Nutrition Assistance Program (SNAP) participants in Fayette County, Kentucky. Public Health Nutrition, 16(7), 1229-1237. http://dx.doi.org/10.1017/S1368980013000505

Hasin, A., Smith, S., \& Stieren, P. (2014). Illinois farmers markets using EBT: Impacts on SNAP redemption and market sales. Journal of Agriculture, Food Systems, and Community Development, 5(1), 179-188. http://dx.doi.org/10.5304/jafscd.2014.051.015

Hendrickson, D., Smith, C., \& Eikenberry, N. (2006). Fruit and vegetable access in four low-income food deserts communities in Minnesota. Agriculture and Human Values, 23(3), 371-383. http://dx.doi.org/10.1007/s10460-006-9002-8

Herman, D. R., Harrison, G. G., Afifi, A. A., \& Jenks, E. (2008). Effect of a targeted subsidy on intake of fruits and vegetables among low-income women in the Special Supplemental Nutrition Program for Women, Infants, and Children. American Journal of Public Health, 98(1), 98-105. http://dx.doi.org/10.2105/ajph.2005.079418

Holben, D. H. (2010). Farmers' markets: Fertile ground for optimizing health. Journal of the American Dietetic Association, 110(3), 364-365. http://dx.doi.org/10.1016/j.jada.2009.11.015

Illinois Department of Agriculture. (2011). Implementing a new or improving your existing EBT program [PowerPoint presentation]. Retrieved from https://www.agr.state.il.us/farmersmarket/Creatin g\%20an\%20EBT\%20program.pptx

Jones, P., \& Bhatia, R. (2011). Supporting equitable food systems through food assistance at farmers' markets. American Journal of Public Health, 101(5), 781-783. http://dx.doi.org/10.2105/AJPH.2010.300021

Joy, A. B., Bunch, S., Davis, M., \& Fujii, J. (2001). USDA program stimulates interest in farmers' markets among low-income women. California Agriculture, 55(3), 38-41. http://dx.doi.org/10.3733/ca.v055n03p38

Kaye, L., Lee, E., \& Chen, Y. Y. (2013). Barriers to food stamps in New York State: A perspective from the field. Journal of Poverty, 17(1), 13-28. http://dx.doi.org/10.1080/10875549.2012.747995

Krokowski, K. (2014). Evaluating the economic and nutritional benefits and program challenges of EBT programs at farmers' markets. Journal of Agriculture, Food Systems, and Community Development, 4(2), 37-44. http://dx.doi.org/10.5304/jafscd.2014.042.011

Kropf, M. L., Holben, D. H., Holcomb, J. P., \& Anderson, H. (2007). Food security status and produce intake and behaviors of Special Supplemental Nutrition Program for Women, Infants, and Children and Farmers' Market Nutrition Program participants. Journal of the American Dietetic Association, 107(11), 1903-1908. http://dx.doi.org/10.1016/j.jada.2007.08.014

Kunkel, M. E., Luccia, B., \& Moore, A. C. (2003). Evaluation of the South Carolina Seniors Farmers' Market Nutrition Education Program. Journal of the American Dietetic Association, 103(7), 880-883. http://dx.doi.org/10.1016/S0002-8223(03)00379-1

Larsen, K., \& Gilliland, J. (2009). A farmers' market in a food desert: Evaluating impacts on the price and availability of healthy food. Health and Place, 15(4), 1158-1162. http://dx.doi.org/10.1016/ j.healthplace.2009.06.007

Leone, L. A., Beth, D., Ickes, S. B., MacGuire, K., Nelson, E., Smith, R. A.,...Ammerman, A. S. (2012). Attitudes toward fruit and vegetable consumption and farmers' market usage among low-income North Carolinians. Journal of Hunger and Environmental Nutrition, 7(1), 64-76.

http://dx.doi.org/10.1080/19320248.2012.651386

Lester, S. (1999). An introduction to phenomenological research. Stan Lester Developments. Retrieved from https://www.rgs.org/NR/rdonlyres/F50603E041AF-4B15-9C84-BA7E4DE8CB4F/0/Seaweed phenomenologyresearch.pdf

McCormack, L. A., Laska, M. N., Larson, N. I., \& Story, M. (2010). Review of the nutritional implications of farmers' markets and community gardens: A Call for evaluation and research efforts. Journal of the American Dietetic Association, 110(3), 399-408. http://dx.doi.org/10.1016/j.jada.2009.11.023

Milwaukee County Winter Farmers' Market. (n.d.). About MCWFM. Retrieved June 13, 2016, from http://www.mcwfm.org/about-us/

Montri, D. N., Behe, B. K., \& Chung, K. (2013). Using a case approach to assess farmers' attitudes regarding central terminal model Electronic Benefits Transfer (EBT) programs at selected Michigan farmers markets. HortTechnology, 23(1), 38-43. Retrieved from http://horttech.ashspublications.org/ content $/ 23 / 1 / 38$.full 
National Association of Farmers' Market Nutrition Programs. (2001). Program impact report for the 2000 WIC Farmers' Market Nutrition Program. Washington, D.C.: Author.

Neumark-Sztainer, D., Story, M., Resnick, M. D., \& Blum, R. W. (1996). Correlates of inadequate fruit and vegetable consumption among adolescents. Preventive Medicine, 25(5), 497-505. http://dx.doi.org/10.1006/pmed.1996.0082

Oberholtzer, L., Dimitri, C., \& Schumacher, G. (2012). Linking farmers, healthy foods, and underserved consumers: Exploring the impact of nutrition incentive programs on farmers and farmers' markets. Journal of Agriculture, Food Systems, and Community Development, 2(4), 63-77. http://dx.doi.org/10.5304/jafscd.2012.024.002

Owens, N., \& Verel, K. (2010). SNAP/EBT at your farmers market: Seven steps to success. Project for Public Spaces and Wholesome Wave. Retrieved from http://www.pps.org/reference/referencecategories/markets-articles/

Parsons, M., \& Morales, A. (2013). Starting a Supplemental Nutrition Assistance Program: Information for starting this program at a farmers market. Journal of Extension, 51(1), 1TOT5. Retrieved from http://www.joe.org/joe/2013february/tt5.php

Payne, T. (2002). U.S. farmers' markets 2000: A study of emerging trends. Journal of Food Distribution Research, 33(1), 173-175. Retrieved from http://purl.umn.edu/27625

Payne, G. H., Wethington, H., Olsho, L., Jernigan, J., Farris, R., \& Walker, D. K. (2013). Implementing a farmers market' incentive program: Perspectives on the New York City Health Bucks program. Preventing Chronic Disease, $2013(10), 120285$. http://dx.doi.org/10.5888/pcd10.120285

Pirog, R. S., \& McCann, N. W. (2009). Is local food more expensive? A consumer price perspective on local and nonlocal foods purchased in Iowa. Leopold Center for Sustainable Agriculture. Retrieved from http://lib.dr.iastate.edu/leopold pubspapers

Robert Wood Johnson Foundation. (n.d.). Qualitative research guidelines project: Member checks. Retrieved from http://www.qualres.org/HomeMemb$\underline{3696 . h t m l}$

Roper, N. (2012, January 18). SNAP redemptions at farmers markets exceed $\$ 11$ million in 2011 [Online news item]. Retrieved from http://farmersmarket coalition.org/snap-redemptions-at-farmersmarkets-exceed-11m-in-2011/

Roper, N., \& Miller, S. (2013, February 15). Slow and steady: Farmers market SNAP sales continue to expand [Online news item]. Retrieved from http:// farmersmarketcoalition.org/snap-sales-upin-2012

Rose, D., \& Richards, R. (2004). Food store access and household fruit and vegetable use among participants in the US Food Stamp Program. Public Health Nutrition, 7(8), 1081-1088. http://dx.doi.org/10.1079/PHN2004648

Roubal, A. M. (2015). The food environment and health: Roles fast food/fast casual restaurants and farmers markets can play (Doctoral dissertation). Retrieved from ProQuest Dissertations and Theses.

Ruelas, V., Iverson, E., Kiekel, P., \& Peters, A. (2012). The role of farmers' markets in two low income, urban communities. Journal of Community Health, 37(3), 554-562. http://dx.doi.org/10.1007/s10900011-9479-y

Simons-Morton, B., McLeroy, K. R., Wendel, M. L. (2012). Behavior theory in health promotion, practice, and research. Burlington, Massachusetts: Jones \& Bartlett.

Stern, P. N. (1980). Grounded theory methodology: Its uses and processes. Image, 12(1), 20-23. http://dx.doi.org/10.1111/j.1547-5069.1980. tb01455.x

Suarez-Balcazar, Y., Martinez, L. I., Cox, G., \& Jayraj, A. (2006). African Americans' views on access to healthy foods: What a farmers' market provides. Journal of Extension, 44(2), 2FEA2. Retrieved from http://www.joe.org/joe/2006april/a2.php

Treuhaft, S., \& Karpyn, A. (2010). The grocery gap: Who has access to healthy food and why it matters. Oakland, California: PolicyLink \& The Food Trust. Retrieved from http://thefoodtrust.org/what-we-do/ $\underline{\text { supermarkets }}$

U.S. Department of Agriculture, Agriculture Marketing Service [USDA AMS]. (n.d.). Farmers market promotion program. Retrieved from http://www.ams.usda.gov/services/grants/fmpp

USDA AMS. (2014). National count of farmers market directory listing graph: 1994-2014 [Graph]. Retrieved from http://dairyprogramhearing.com/ ams.fetchTemplateDatadb6adb6a.html 
USDA, Agricultural Marketing Service. (2016). Local Food Directories: National Farmers Market Directory. Retrieved from https://www.ams.usda.gov/localfood-directories/farmersmarkets

USDA, Food and Nutrition Service [USDA FNS]. (2014a). Supplemental Nutrition Assistance Program (SNAP): A short history of $S N A P$. Retrieved from http://www.fns.usda.gov/snap/short-history-snap

USDA FNS. (2014b). Nutrition assistance in farmers markets: Understanding the shopping patterns of SNAP participants. Retrieved from http://www.fns.usda. gov/sites/default/files/FarmersMarkets-ShoppingPatterns-Summary.pdf

U.S. Census Bureau. (2013). American Community Survey [Data table]. Retrieved from https://www.census.gov/data.html

University of Wisconsin-Madison \& Journal of Agriculture, Food Systems, and Community Development. (n.d.) Food system wiki. Retrieved June 10, 2016, from http:// foodglossary.pbworks. com/w/page/48861772/Farmers $\% 20$ market

Virginia Farmers Market Association. (n.d.). SNAP/EBT tool kit. Retrieved from http://www.vfmma.org/instructional/snapebttool-kit

Ward, R., Slawson, D., Wu, Q., Pitts, S. J. (2015). Association between farmers market managers' motivations and market-level Supplemental Nutrition Assistance Program Electronic Benefit Transfer (SNAP/EBT) availability and business vitality. Journal of Food Systems, Agriculture, and Community Development, 6(1), 121-130. http://dx.doi.org/10.5304/jafscd.2015.061.010

Wetherill, M. S., \& Gray, K. A. (2015). Farmers' markets and the local food environment: Identifying perceived accessibility barriers for SNAP consumers receiving Temporary Assistance for Needy Families (TANF) in an urban Oklahoma community. Journal of Nutrition Education and Behavior, 47(2), 127el-133.e1.

http://dx.doi.org/10.1016/j.jneb.2014.12.008

Wolf, M. M., Spittler, A., \& Ahern, J. (2005). A profile of farmers' market consumers and the perceived advantages of produce sold at farmers' markets. Journal of Food Distribution Research, 36(1), 192-201. http://purl.umn.edu/26768

Young, C. R., Aquilante, J. L., Solomon, S., Colby, L., Kawinzi, M. A., Uy, N., \& Mallya, G. (2013). Improving fruit and vegetable consumption among low-income customers at farmers markets: Philly Food Bucks, Philadelphia, Pennsylvania, 2011. Preventing Chronic Disease, 10. http://dx.doi.org/10.5888/pcd10.120356 


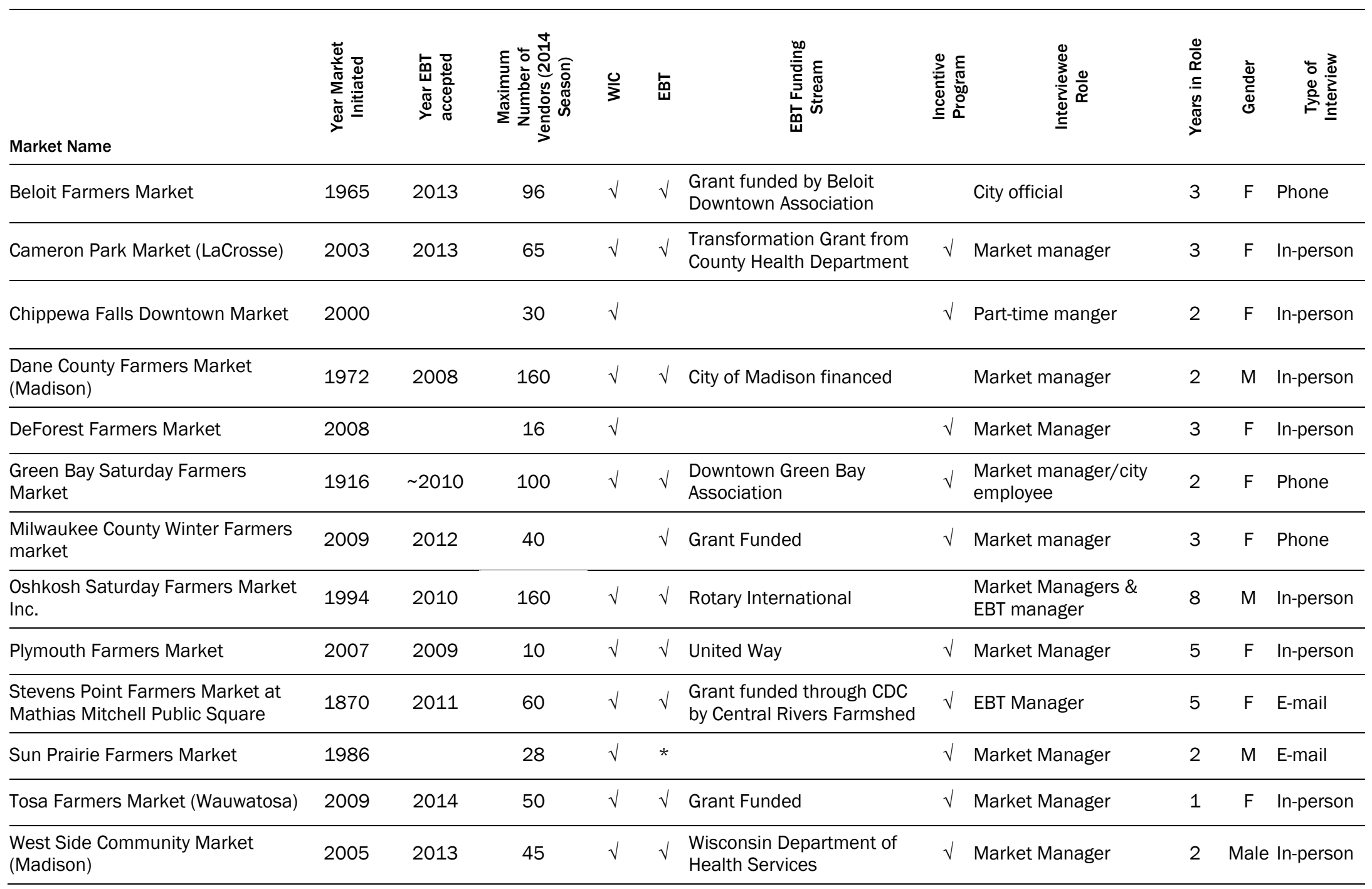

